\title{
Wybrane źródła finansowania innowacji społecznych na świecie
}

\begin{abstract}
Marta Kołodziej-Hajdo
Streszczenie: Innowacje społeczne są istotnym elementem polityki innowacyjnej, odnoszącym się do rozwiązywania problemów społecznych oraz tworzenia wartości w obszarach służących społeczeństwu. Jedną z determinant ich wprowadzania jest zapewnienie odpowiednich źródeł ich finansowania. Celem rozdziału jest prezentacja dostępnych i potencjalnych źródeł finansowania innowacji społecznych. Z uwagi na bardzo złożoną strukturę finansowania innowacji społecznych i zróżnicowanie sposobów pozyskiwania funduszy, w rozdziale skoncentrowano się przede wszystkim na głównych, najczęściej wykorzystywanych i charakteryzujących się największą dostępnością formach finansowania: środkach Unii Europejskiej i jej instytucji, budżetowaniu partycypacyjnemu i crowdfundingu. W pracy posłużono się metodą desk research, dokonując również autorskiego przeglądu dostępnej literatury przedmiotu, zasobów internetowych i raportów analitycznych. Przeprowadzone badania wskazują, że kluczowym czynnikiem sukcesu powinno być rozszerzenie instrumentów i zasad finansowania innowacji społecznych. Chodzi przede wszystkim o wykorzystanie nowatorskich instrumentów finansowania oraz rozwój współpracy międzysektorowej.
\end{abstract}

Słowa kluczowe: źródła finansowania; innowacja społeczna; instrument finansowania

Kody JEL: $\quad$ D24, 025,031

\section{Wprowadzenie}

Rozwój społeczno-gospodarczy nie jest możliwy bez wspierania dynamizacji i wdrażania innowacji, także innowacji społecznych. Dąży do tego wiele państw, nie tylko Unii Europejskiej, których celem jest stworzenie kolektywnego rynku innowacji bez barier czy ograniczeń. Głównym narzędziem stymulowania innowacji społecznych są odpowiednie mechanizmy ich finansowania. Takie, które zwiększą efektywność organizacji i ich usług ukierunkowanych na innowacyjne rozwiązywanie problemów społecznych.

Realizacja przedsięwzięć w obszarze innowacji społecznych nie jest możliwa bez odpowiedniego finansowania. Podmioty wdrażające tego typu projekty wskazują, że główną barierą ich realizacji jest brak wsparcia finansowego (EGO, 2018). Stąd też zagadnienie sposobów finansowania innowacji społecznych, ich dostępności oraz mechanizmu zmian jest kwestią istotną.

Celem rozdziału jest prezentacja dostępnych i potencjalnych źródeł finansowania innowacji społecznych. Z uwagi na bardzo złożoną strukturę finansowania innowacji społecznych i zróżnicowanie sposobów pozyskiwania funduszy, często bardzo rozdrobnionych, w rozdziale skoncentrowano się przede wszystkim na głównych, najczęściej wykorzystywanych i charakteryzujących się największą dostępnością formach finansowania: środkach Unii Europejskiej i jej instytucji, budżetowaniu partycypacyjnemu i crowdfundingu. 
W pracy posłużono się metodą desk research, dokonując również autorskiego przeglądu dostępnej literatury przedmiotu, zasobów internetowych i raportów analitycznych.

\section{Finansowanie inwestycji społecznych}

Innowacje, których popularność rosła na przestrzeni XX wieku pierwotnie dotyczyły przede wszystkim postępu technologicznego. Pojęcie „innowacje społeczne” (social innovation) w literaturze pojawiło się po raz pierwszy w latach 50. XX w. (Solow, 1957) i oznaczało ono głównie badania eksperymentalne w dziedzinie nauk społecznych i humanistycznych. Jednocześnie w tym czasie podejmowano już wiele innowacyjnych działań, które miały za zadanie rozwiązanie także problemów natury społecznej. Dotyczyły one głównie ochrony zdrowia.

Autorem, który w znaczący sposób przyczynił się do wyodrębnienia innowacji społecznych w badaniach był Peter F. Drucker, który w swojej publikacji z 1957 r. zauważył, że innowacje społeczne są bardziej potrzebne niż technologiczne (Drucker, 1957).

W rozwijającej się gospodarce i społeczeństwie, której rozwój determinuje bardziej złożone życie społeczne i pojawienie się nowych problemów jak: starzenie się społeczeństwa, migracje, dyskryminacja społeczna, problemy w obszarze zatrudnienia itd., innowacje społeczne stały się potrzebne. Wyrazem tego jest chociażby ich uwzględnienie w strategicznych dokumentach na poziomie europejskim (Komisja Europejska, 2010).

Podstawowym rezultatem procesu innowacji społecznej powinny być nowatorskie pomysły. Jednak każdy pomysł, bez względu na jego zakres, adresatów, poziom zaangażowanych zasobów wymaga wysiłku w celu jego realizacji. Rzeczą oczywistą jest, że innowacje społeczne nie są możliwe bez trwałego finansowania.

W raporcie oceniającym efektywność wdrażania innowacji społecznych na świecie, mierzoną indeksem efektywności, filar dotyczący finansowania stawiany jest na drugim miejscu (po: uwarunkowaniach politycznych i instytucjonalnych), z punktu widzenia sukcesu innowacji społecznej, a jego waga stanowi 22,2\% w całości wskaźnika (Old Problems, 2016).

Z uwagi na fakt, że innowacje społeczne mogą być wdrażane w różnych obszarach, przez różne środowiska czy organizacje, opcje finansowania są szerokie i bardzo zróżnicowane.

Ponieważ innowacje społeczne mogą być realizowane zarówno w sektorze prywatnym, jak i publicznym niektóre inicjatywy sfinansowane są częściowo lub całkowicie ze źródeł komercyjnych, inne mogą otrzymywać dotacje, granty od organizacji działających w obszarze społecznej odpowiedzialności biznesu bądź instytucji publicznych (krajowych czy zagranicznych). Często finansowanie innowacji społecznych ma charakter finansowania hybrydowego.

Analiza złożoności finansowania innowacji społecznych, wyrażona we wspomnianym indeksie wskazuje, że ok. 50\% środków na finansowanie projektów w tym obszarze pochodzi ze środków publicznych (jest to udział ustalony w wyniku analizy źródeł finansowania innowacji społecznych w 45 krajach świata). Mowa tu o: funduszach innowacji społecznych pozyskiwanych ze środków krajowych czy unijnych, finansowaniu partycypacyjnym, wspieraniu przedsięwzięć przez społeczne inkubatory i inne organizacje publiczne, które posiadają zasoby pozwalające na wspomaganie innowacji społecznych, konkursy, granty przekazywane przez instytucje publiczne.

Drugą część stanowią środki o charakterze prywatnym, których źródłem mogą być: fundacje działające w ramach społecznej odpowiedzialności biznesu, banki i fundusze inwestycyjne dedykowane temu obszarowi, crowdfunding, czy wypracowane przez organizacje wdrażające innowacje społeczne zyski itp. 


\section{Fundusze Unii Europejskiej w finansowaniu innowacji społecznych}

Obecnie w Polsce i krajach Unii Europejskiej źródłem finansowania tworzenia i wdrażania innowacyjnych pomysłów w obszarze społecznym, dla projektów realizowanych w skali mikro czy makro, są środki przekazywane przez Unię Europejską w ramach funduszy strukturalnych, czy też pochodzące od innych instytucji europejskich w ramach podejmowanych przez nich inicjatyw.

Podstawowym dokumentem, który określa kwestie wsparcia finansowego innowacji społecznych jest Strategia Europa 2020 (Komisja Europejska, 2010). W dokumencie tym zwrócono uwagę na konieczność wykorzystania innowacji na rzecz sprostania wyzwaniom, przed którymi stoi społeczeństwo, proponując także tworzenie europejskich partnerstw innowacji służących rozwiązywaniu głównych problemów społecznych. Jednocześnie państwa członkowskie zostały zobligowane do stosowania bardziej innowacyjnego podejścia w zakresie finansowania z wykorzystaniem zróżnicowanych instrumentów. Podejście to będzie kontynuowane w strategii Europa 2030.

Unia Europejska stworzyła szereg instrumentów finansowych wspierających innowacyjne praktyki dotyczące kwestii społecznych i socjalnych. Są to programy o różnym charakterze, angażujące mniejsze lub większe środki finansowe. Finansowane są one głównie przez Europejski Fundusz Społeczny (EFS), ale także i inne fundusze i programy. Natomiast działania sektora publicznego powinny zostać wsparte aktywnościami przedsiębiorstw społecznych i podmiotami trzeciego sektora, a także poprzez udział sektora prywatnego i inżynierii finansowej, poprzez stosowanie takich instrumentów jak: mikrofinansowanie, gwarancje oparte na polityce i obligacje w dziedzinie inwestycji społecznych (Komisja Europejska, 2013). Jednym z głównych instrumentów Unii Europejskiej, wdrażającym strategię Europa 2020 jest polityka spójności.

Aktem prawnym, który przekłada cele strategii na działania funduszy UE jest Rozporządzenie Parlamentu Europejskiego i Rady z 2013 (UE) nr 1303/2013.

Rola, jaka została przypisana innowacjom społecznym przez Unię Europejską jest widoczna w tym dokumencie między innymi poprzez nałożenie obowiązku raportowania postępów działań w dziedzinie innowacji społecznych (Rozporządzenie Parlamentu Europejskiego i Rady (UE) nr 1303/2013, art. 111, ust. 4g). Przepis ten obliguje państwa członkowskie, aby w rocznych sprawozdaniach z realizacji swoich programów operacyjnych przedstawiały również postępy w realizacji działań w dziedzinie innowacji społecznych.

Europejski Fundusz Społeczny ma promować innowacje społeczne we wszystkich obszarach objętych jego zakresem, „w szczególności w celu badania i zwiększenia możliwości innowacyjnych rozwiązań na rzecz realizacji potrzeb społecznych we współpracy z odpowiednimi partnerami" (Rozporządzenie Parlamentu Europejskiego i Rady (UE) nr 1304/2013, art. 9).

Obecnie, w ramach tego funduszu, programem najbardziej odpowiednim do finansowania innowacji społecznych jest Program Operacyjny Wiedza, Edukacja i Rozwój, w którym jedna oś (IV) jest dedykowana innowacjom społecznym. Na realizację projektów w ramach tego priorytetu przeznaczono 711 mln euro W Polsce w obszarze tej osi priorytetowej, do końca 2018 r., do dofinansowania przyjęto 662 innowacje, w tym 32 w skali makro i 630 w skali mikro (Sprawozdanie z wdrażania, 2019).

Innowacje społeczne zostały także wymienione wśród priorytetów inwestycyjnych Europejskiego Funduszu Rozwoju Regionalnego, gdzie dofinansowanie odbywa się głównie za pośrednictwem regionalnych programów operacyjnych. 
Unia Europejska, obecnie dla okresu 2014-2020, wspiera innowacje społeczne także przy pomocy innych instrumentów finansowania takich jak:

- Europejski Fundusz Rolny na rzecz Rozwoju Obszarów Wiejskich,

- Horyzont 2020,

- Program na rzecz konkurencyjności przedsiębiorstw i MŚP (COSME) 2014-2020.

- Social Innovation Tournament - międzynarodowy konkurs na innowacje społeczne ogłaszany co roku od 2012 r. przez European Investment Bank (The Social Innovation Tournament, 2019).

- European Social Innovation Competition - międzynarodowy konkurs ogłaszany co roku przez Komisję Europejską

- Program Employment and Social Innovation (EaSI) - program Komisji Europejskiej, działający od 2014, w ramach którego można aplikować na środki m.in. w obszarze innowacji społecznych (Regulation (EU) No 1296/2013).

Jak wskazano, obecnie w Polsce, ale i w innych krajach Europy, znaczącym źródłem finansowania innowacji społecznych, zarówno w skali makro, jak i mikro są środki pochodzące z Unii Europejskiej. Na przestrzeni kilkudziesięciu lat wypracowano wiele polityk, programów i inicjatyw, które mają przyczynić się do wdrażania innowacji społecznych. Działania te mają charakter procesu ciągłego.

\section{Fundusze publiczne - budżet partycypacyjny}

W obecnych czasach naturalnym źródłem finansowania wielu projektów realizowanych w ramach innowacji społecznych, adresowanych do społeczności zawężonej terytorialnie jest budżet partycypacyjny. Na świecie i w Polsce ta forma finansowania publicznego zyskuje na popularności.

Definicji pojęcia „budżetowanie partycypacyjne” jest wiele. Wynika to z faktu, że w różnych krajach pod tą nazwą funkcjonuje wiele różnych, odmiennych rozwiązań, procedur czy instytucji (Czarnecki, 2014, s. 127).

Agenda ONZ, zajmująca się zagadnieniami urbanizacji UN-HABITAT, wskazuje, że jest to mechanizm/proces, poprzez który ludność decyduje lub przyczynia się do podejmowanych decyzji dotyczących sposobu przeznaczenia całości lub części dostępnych środków publicznych (Cabannes, 2004, s. 20). Oznacza to, że budżet partycypacyjny jest instrumentem bezpośredniej partycypacji obywateli w procesie decydowania o sposobie wydatkowania dostępnych środków budżetowych na wskazane przez mieszkańców czy instytucje społeczne projekty, często o charakterze innowacyjnym.

B. Wampler, badacz budżetów partycypacyjnych pisze, że: „budżet partycypacyjny jest procesem podejmowania decyzji, poprzez który obywatele dyskutują i negocjują nad dystrybucją publicznych zasobów" (Wampler, 2007, s. 21). Można więc stwierdzić, że budżet partycypacyjny stanowi publiczne źródło finansowania wielu projektów, których celem jest rozwiązanie problemów przede wszystkim społeczności lokalnej, czy jej poszczególnych grup i późniejszym monitorowaniu ich realizacji.

W wielu krajach zagadnienie to znalazło unormowanie prawne, jednak w polskim systemie prawnym, w tym w regulacjach dotyczących funkcjonowania samorządu terytorialnego do niedawna brak było przepisów definiujących, jak i określających zasady realizacji budżetu partycypacyjnego. Dopiero ustawa z 11 stycznia 2018 r. (Ustawa..., 2018) prezentuje definicję i zasady funkcjonowania tej formy finansowania projektów służących lokalnej społeczności. 
Polscy badacze zagadnienia budżetu: M. Kulesza oraz D. Sześciło podkreślają, że „prowadzenie procesu budżetowego metodą partycypacyjną jest techniką, w której budżet opracowuje się z szerokim udziałem obywateli, wykraczającym poza tradycyjne konsultacje społeczne. Podstawową zaletą budżetów partycypacyjnych jest łączenie dwóch zróżnicowanych potrzeb: bardziej efektywnego i racjonalnego gospodarowania pieniędzmi publicznymi oraz podniesienia jakości demokracji. Wzmacnia się kontrolę nad wydatkami publicznymi i inicjuje szerszą, bardziej pogłębioną dyskusję na ich temat. Zapewnia się warunki dla większej partycypacji obywatelskiej i podnoszenia wiedzy obywateli na temat spraw publicznych" (Kulesza i Sześciło, 2013, s. 123-124).

Aby budżet partycypacyjny był wdrażany efektywnie, powinien charakteryzować się określonymi atrybutami:

- wiążącym charakterem dla władz samorządowych, oznaczającym obligatoryjność realizacji inwestycji wybranych przez mieszkańców;

- być opartym na przejrzystych procesach tworzenia i zarządzania;

- posiadać inkluzyjny charakter, a więc umożliwiać włączenie się wszystkich chętnych podmiotów;

- opierać się na zasadzie równości stron (mieszkańców, urzędników, ekspertów, władz samorządowych);

- wspierać aktywność mieszkańców;

- mieć charakter regularny, ciągły, powtarzalny (nie powinna to być inicjatywa jednorazowa);

- rozsądnie wysoki, a nie symboliczny (Kraszewski i Mojkowski, 2014, s. 4).

Z przedstawionych definicji i cech wynikają trzy zasadnicze funkcje jakie pełni to źródło finansowania innowacji społecznych. Po pierwsze funkcja ekonomiczna, która pozwala na pozyskanie środków niezbędnych do realizacji wskazanych przez lokalną społeczność projektów. W drugiej kolejności funkcja aktywizacyjna, co przejawia się zaangażowaniem mieszkańców w sprawy lokalne. I w końcu funkcja informacyjna, czyli pozyskiwanie danych wykorzystywanych w podejmowaniu decyzji na różnych etapach realizacji działań projektów społecznych.

Reasumując, budżet partycypacyjny jest mechanizmem z najwyższego poziomu partycypacji obywatelskiej - instrumentem, który pozwala obywatelom współdecydować o wydatkowaniu części środków publicznych. Jest to narzędzie, które nie tylko umożliwia realizację szczególnego podejścia do myślenia o funkcjonowaniu społeczności lokalnych, ale przede wszystkim pozwala zwiększać aktywność mieszkańców w zakresie wprowadzania innowacji społecznych.

Literatura przedmiotu (Gilman, 2016; Goldfrank, 2007; Goldsmith, Georges i Burke, 2010; Bornstein i Davis, 2010) wskazuje, że korzystanie z budżetowania partycypacyjnego wpływa na wzrost poziomu dobrobytu mieszkańców, jak również przyczynia się do rozwiązania wielu społecznych problemów na szczeblu lokalnym czy regionalnym. Jednocześnie stwarza warunki instytucjonalne dla rozwoju lokalnych społeczności oraz aktywizacji obywatelskiego uczestnictwa w samorządzie lokalnym.

Budżetowanie partycypacyjne łączy więc systemową pomoc organizacyjną i finansową dla realizacji społecznych, często innowacyjnych, projektów, zgłaszanych przez mieszkańców czy organizacje działające na danym terenie oraz władz lokalnych, których celem jest rozwiązanie wskazanych problemów społecznych. Ten mechanizm pozwala na zwiększenie efektywności wykorzystania środków publicznych, generowanie nowych pomysłów, ale także tworzy platformę dialogu między obywatelami a władzami. 
Zaangażowanie mieszkańców w rozwój innowacji społecznych wiąże się z wykorzystaniem ich wiedzy, idei, koncepcji i działań, co wynika ze znajomości potrzeb i problemów społeczności, w których funkcjonują. Sami mieszkańcy są często źródłem informacji i inspiracji już na etapie budowania założeń i koncepcji innowacji społecznych (Olejniczuk-Merta, 2013, s. 26).

Zaangażowanie społeczności lokalnej jest pomocne w wyszukiwaniu i precyzowaniu zagadnień społecznych, które po nadaniu im priorytetów pozwolą na przygotowanie odpowiedzialnych i skutecznych programów. Tak zdefiniowane płaszczyzny społeczne pomagają wyznaczyć kierunki aktywności, w których będzie miało miejsce większe zaangażowanie mieszkańców w proces rozwoju związanych z nimi innowacji.

Ludność i działające na danym terytorium organizacje powinny mieć poczucie wpływu na rozwój swojego otoczenia, w tym kierunki innowacji społecznych. Dla zwiększenia ich aktywności społecznej istotne jest zorientowanie się, jakie obszary społeczne ich interesują i które chcieliby poprzeć własnym zaangażowaniem, a także włączenie ich w rozwój i wprowadzanie innowacyjnych rozwiązań.

Budżetowania partycypacyjne jest jedną z form finansowania innowacji społecznych, ale zawężonych terytorialnie, bo adresowanych do lokalnej społeczności.

\section{Fundusze społecznościowe - Crowdfunding}

Innowacje społeczne można rozpatrywać także przez pryzmat crowdfundingu jako prywatnego źródła finansowania. Termin "crowdfunding” pochodzący z języka angielskiego oznacza gromadzenie zasobów finansowych z (internetowego) „tłumu”. W literaturze polskojęzycznej nazwano ten mechanizm "finansowaniem społecznościowym".

Crowdfunding to różnorodny zbiór strategii i mechanizmów wspierających działalność fundraisingową przez innowacyjne i przedsiębiorcze projekty (Freedman i Nutting, 2015).

Istota tego mechanizmu polega na pozyskiwaniu funduszy na realizację przedsięwzięć od społeczności internetowej. W definicjach crowdfundingu zaznacza się, że pozyskiwane w ten sposób środki finansowe pochodzą zazwyczaj od dużej grupy, której uczestnicy wspierają określone idee, innowacje, przekazując za pomocą internetu (dedykowanych platform crowdfundingowych) relatywnie niewielkie kwoty (Belleflamme, Lambert i Schwienbacher 2014; Bradford, 2012; Dziuba, 2015). Ponadto proces ten umożliwia pozyskiwanie dodatkowych informacji oraz kreowanie więzi z dostarczycielami funduszy.

O tym, z jak dużym potencjałem w przypadku tego sposobu pozyskiwania funduszy na innowacje mamy do czynienia, świadczą jego odmiany (Fleming i Sorenson, 2016, s. 7-8; Brunello, 2014, s. 40-54; Lambert i Schwienbacher, 2010, s. 5-7):

- model donacyjny, współfinansujący nie otrzymuje żadnego świadczenia zwrotnego,

- model bonusowy, który jest najbardziej popularnym modelem wiążącym się z przekazywaniem użytkownikom fizycznych czy cyfrowych nagród (mających niejednokrotnie emocjonalny wymiar) jako nagrodę za dokonane wpłaty,

- model udziałowy, który stosowany jest w przypadku zakładania firm,

- model pożyczkowy, będący pożyczką między osobami prywatnymi, działający zgodnie z mechanizmem aukcji malejącej, w której osoba starająca się o pożyczkę wybiera tego pożyczkodawcę, który oczekuje najniższego oprocentowania.

Biorąc pod uwagę ciągły rozwój finansowania społecznościowego, należy przypuszczać, że pojawią się kolejne modele, które będą wywodziły się z czterech wymienionych wyżej grup, oparte na społecznościach zogniskowanych wokół danej innowacji bądź terytorium. 
Potencjał crowdfundingu w kreowaniu innowacji polega na tym, że uczestnicy tego procesu mają możliwość wspierania wartościowych, posiadających niejednokrotnie społeczne wymiary idei, pomysłów w bardzo zróżnicowanych obszarach, które dzięki temu stają się realne.

Finansowanie poprzez crowdfunding, obok pozyskania odpowiednich środków pieniężnych, może wnosić wartość dodaną. Może spowodować, że wcielane w życie innowacje społeczne będą lepiej odzwierciedlać wartości, potrzeby i zainteresowania dostarczających fundusze. Korzyści z wykorzystywania crowdfundingu w obszarze innowacji społecznych mogą uzyskać wszystkie grupy, zarówno donatorzy, jak i obdarowani, a zakres tych korzyści uzależniony jest od stosowanego modelu.

Crowdfunding jest zatem kolejnym mechanizmem pozwalającym na pozyskiwanie funduszy w celu finansowania innowacyjnych pomysłów, także takich, w przypadku których klasyczne formy finansowania nie są możliwe.

\section{Finansowanie innowacji społecznych - inne źródła}

Wymienione wyżej źródła pozyskiwania funduszy nie są jedyną możliwością finansowania tworzenia i wdrażania innowacyjnych pomysłów w obszarze społecznym.

Coraz mocniejsze akcentowanie problematyki innowacji społecznych w Polsce i na świecie wpłynęło ona pojawienie się wielu, zróżnicowanych instytucji i instrumentów finansowego wsparcia. Należy tutaj wymienić między innymi:

- bankowość społeczną - instytucje bankowe specjalizujące się w finansowaniu działań w sektorze społecznym, szczególnie dla organizacji non-profit. Można tutaj wymienić m.in. Banca Prossima we Włoszech, Crédit Coopératif we Francji, TriodosBank w Niderlandach i Belgii, czy CharityBank w Wielkiej Brytanii,

- społeczne fundusze inwestycyjne, których głównym celem jest zapewnienie przedsiębiorstwom społecznym i organizacjom charytatywnym niedrogiego, zwrotnego finansowania. Przykładami są: CAF Venturesome, The Big Issue Invest w Wielkiej Brytanii, Fondazione CRT we Włoszech,

- instytucje i organizacje o zasięgu międzynarodowym, które poprzez doradztwo, fundusze, wspierają innowacje społeczne. Do najbardziej znanych należy zaliczyć: ASHOKA, EBN Innovation Network, Kennisland Foundation, NESTA w Wielkiej Brytanii, The Young Foundation,

- inkubatory i lokalne centra przedsiębiorczości społecznej wspierające czy inwestujące w obszarze innowacji społecznych. Należy tutaj zaliczyć, np. Campus, Center for Social Innovation w Nowym Jorku i Toronto, Impact HUB, NESST,

- fundacje działające przy firmach, które w ramach strategii społecznej odpowiedzialności biznesu (CSR) wspierają merytorycznie, prawnie czy finansowo innowacje społeczne. W Polsce można tu wymienić, np.: Kulczyk Foundation, ORLEN Fundacja, Fundacja KGHM Polska Miedź, Fundacja Banku Pekao S.A. imienia dr. Mariana Kantona i inne.

Przedstawione pozostałe modele i sposoby finansowania stanowią często odpowiednią kombinację finansowania w formie dotacji, pożyczek czy kapitału własnego na różnych etapach wdrażania innowacji społecznych. Zaangażowanie w tej płaszczyźnie dotyczy zarówno instytucji, jak i osób fizycznych z różnych sektorów. 
Należy podkreślić, że omówione formy finansowania innowacji społecznych nie wyczerpują wszystkich możliwości, a jedynie przedstawiono najpopularniejsze i najbardziej dostępne w praktyce.

\section{Podsumowanie}

Wśród wielu barier rozwoju innowacji społecznych, brak zabezpieczenia finansowego uważa się za jedną z najbardziej istotnych, jeśli nie najważniejszą.

Jak pokazują badania (EGO, 2018), środki na innowacje społeczne są niewystarczające. Wprawdzie organizacji, które oferują wsparcie finansowe w tym obszarze jest wiele, to jednak dostępność do przekazywanych przez nich funduszy zależy niejednokrotnie od spełnienia wielu kryteriów, często o charakterze czysto formalnym (np. w przypadku ubiegania się o środki unijne, środki krajowe, granty, udział w ogłaszanych konkursach itp.), nierzadko trudnych do spełnienia przez innowatorów.

W wielu przypadkach oferowane środki są zbyt małe w porównaniu ze zgłaszanymi potrzebami czy liczbą zainteresowanych (dotyczy to np. ofert ze strony inkubatorów, czy środków przekazywanych w ramach społecznej odpowiedzialności biznesu). Niejednokrotnie ich pozyskanie związane jest również z przychylnością (budżetowanie partycypacyjne) i ofiarnością społeczeństwa (crowdfunding).

Przeprowadzone badania wskazują, że kluczowym czynnikiem sukcesu powinno być rozszerzenie instrumentów i zasad finansowania innowacji społecznych. Z jednej strony należy zwiększyć wachlarz sposobów zapewnienia kapitału o instrumenty już znane, ale w tym obszarze wdrażane (na świecie) w bardzo znikomym zakresie jak np.: granty replikacyjne, instrumenty zwrotne (pożyczki), udziały czy ulgi podatkowe w obszarze inwestycji w innowacje społeczne. Chodzi tu także o bardziej nowatorskie instrumenty, jak chociażby: społeczne fundusze inwestycyjne czy bankowość społeczną.

Z drugiej strony należy podjąć działania w zakresie rozwoju współpracy międzysektorowej (współpraca biznesu z organizacjami społecznymi i sektorem publicznym) czy międzyorganizacyjnej, tworząc finansowanie hybrydowe.

W odniesieniu do powszechnych źródeł finansowania innowacji społecznych należałoby się zastanowić (dotyczy to np. pozyskiwania środków unijnych, grantów itp.) nad uproszczeniem procedury aplikacyjnej.

\section{Literatura}

Belleflamme, P., Lambert, T., Schwienbacher, A. (2014). Crowdfunding: Tapping the right crowd. Journal of Business Venturing, 29(5), 585-609.

Bornstein, D., Davis, S. (2010). Social Entrepreneurship: What Everyone Needs to Know. New York: Oxford University Press.

Bradford, S. (2012). Crowdfunding and the Federal Securities Laws. Columbia Business Law Review, 1(1), 1-150.

Brunello, A. (2014). II manuale del crowdfunding. Milano: LSWR Srl.

Cabannes, Y. (2004). Frequently Asked Questions about Participatory Budgeting. Nairobi: UN-HABITAT, Quito.

Czarnecki, K. (2014). Udział mieszkańców w ustalaniu wydatków budżetu gminy w ramach tzw. budżetu partycypacyjnego (na przykładzie Torunia w latach 2013-2014). Prawo Budżetowe Państwa i Samorzadu, 1(2), 125-145.

Drucker, P. (1957). Landmarks of Tomorrow. New York: Harper.

Dziuba, D.T. (2015). Ekonomika crowdfundingu. Zarys problematyki badawczej. Warszawa: Difin. 
EGO (2018). Raport dla badania pn. „Ewaluacja innowacji społecznych w ramach Programu Operacyjnego Wiedza Edukacja Rozwój". Warszawa: Ministerstwo Funduszy i Polityki Regionalnej. Pobrane z: http://www. ewaluacja.gov.pl/media/75439/Pierwszy_raport_tematyczny_Innowacje.pdf (dostęp: 12.11.2019).

Fleming, L., Sorenson, O. (2006). Financing by and for the Masses: An Introduction to the Special Issue on Crowdfunding. California Management Review, 58(2), 5-19. https://doi.org/10.1525/cmr.2016.58.2.5.

Freedman, D.M., Nutting, M.R. (2015). Equity Crowdfunding for Investors: A Guide to Risks, Returns, Regulations, Funding Portals, Due Diligence and Deal Terms. Hoboken (N.J.): Wiley \& Sons.

Gilman, H.R. (2016). Democracy Reinvented: Participatory Budgeting and Civic Innovation in America. Washington, D.C.: Brookings Institution Press.

Goldfrank, B. (2007). Lessons from Latin America's Experience with Participatory Budgeting. History of Participatory Budgeting. W: S. Anwar (red.). Participatory Budget. Washington: The World Bank.

Goldsmith, S., Georges, G., Burke, T.G. (2010). The Power of Social Innovation. How Civic Entrepreneurs Ignite Community Networks for Good. San Francisco: Jossey-Bass A Wiley Imprint.

Komisja Europejska (2010). Europa 2020. Strategia na rzecz inteligentnego i zrównoważonego rozwoju sprzyjajacego właczeniu społecznemu. Komisja Europejska: Bruksela. Pobrane z: https://eur-lex.europa.eu/legal-content/PL/TXT/PDF/?uri=CELEX:52010DC2020\&from=PL.

Komisja Europejska (2010). Europa 2020. Strategia na rzecz inteligentnego i zrównoważonego rozwoju sprzyjajacego właczeniu społecznemu. Bruksela: Komisja Europejska. Pobrane z: https://eur-lex.europa.eu/LexUriServ/LexUriServ.do?uri=COM:2010:2020:FIN:PL:PDF.

Komisja Europejska (2013). Inwestycje społeczne na rzecz wzrostu i spójności, w tym wdrażanie Europejskiego. Komunikat Komisji do Parlamentu Europejskiego, Rady, Europejskiego Komitetu Ekonomiczno-Społecznego i Komitetu Regionów, Funduszu Społecznego na lata 2014-2020. Komisja Europejska: Bruksela. Pobrane z: https://eur-lex.europa.eu/legal-content/PL/TXT/PDF/?uri=CELEX:52013DC0083\&from=EN.

Kraszewski, D., Mojkowski, K. (2014). Budżet obywatelski w Polsce. Warszawa: Fundacja im. St. Batorego.

Kulesza, M., Sześciło, D. (2013). Polityka administracyjna i zarządzanie publiczne. Warszawa: Wolters Kluwer.

Lambert, T., Schwienbacher, A. (2010). An Empirical Analysis of Crowdfunding. Social Science Research Network, $1578175,1-23$.

Old Problems, New Solutions: Improving acute psychiatric care for adults in England (2016). Commission on Acute Adult Psychiatric Care, London: Royal College of Psychiatrists. Pobrane z: www.crisiscareconcordat.org. uk/inspiration/the-commission-to-review-the-provision-of-acute-inpatient-psychiatric-care-for-adultsfebruary-2016 (dostęp: 20.05.2019).

Olejniczuk-Merta, A. (2013). Innowacje społeczne. Konsumpcja i Rozwój, 1(4), 21-34.

Rozporządzenie Parlamentu Europejskiego i Rady (UE) nr 1296/2013 z dnia 11 grudnia 2013 r. w sprawie programu Unii Europejskiej na rzecz zatrudnienia i innowacji społecznych („EaSI”) i zmieniające decyzję nr 283/2010/UE ustanawiającą Europejski instrument mikrofinansowy na rzecz zatrudnienia i włączenia społecznego Progress.

Rozporządzenie Parlamentu Europejskiego i Rady (UE) nr 1303/2013 z dnia 17 grudnia 2013 r. nr 1303/2013 z dnia 17 grudnia 2013 roku ustanawiające wspólne przepisy dotyczące EFRR, EFS, FS, EFRROW oraz EFMiR.

Rozporządzenie Parlamentu Europejskiego i Rady (UE) nr 1304/2013 z dnia 17 grudnia 2013 r. w sprawie Europejskiego Funduszu Społecznego i uchylające rozporządzenie Rady (WE) nr 1081/2006 (Dz. Urz. UE L 347/470).

Solow, R. M. (1957). Technical Change and the Aggregate Production Function. Review of Economics and Statistics, 39(3), 312-320.

Sprawozdanie z wdrażania Programu Operacyjnego Wiedza Edukacja Rozwój w 2018 r. (2019). Warszawa: Ministerstwo Inwestycji i Rozwoju. Pobrane z: www.power.gov.pl/media/81331/Sprawozdanie_z_POWER_2018. pdf (dostęp: 03.06.2019).

The Social Innovation Tournament - EIB. Institute. Luxembourg. Pobrane z: https://institute.eib.org/whatwedo/ social-2-2/social-innovation-tournament-2/ (dostęp: 03.06.2019).

Ustawa z dnia 11 stycznia 2018 r. o zmianie niektórych ustaw w celu zwiększenia udziału obywateli w procesie wybierania, funkcjonowania i kontrolowania niektórych organów publicznych, Dz.U. 2018, poz. 130.

Wampler, B. (2007). A Guide to participatory budgeting. W: S. Anwar (red.). Participatory Budgeting (s. 21-54). Washington: The Word Bank.

\section{Review of sources of financing social innovations}

Summary: The aim of the chapter is to present currently available as well as the potential sources of financing for social innovations. The method of desk research was used in the work, also a review of published prior research, internet resources and analytical reports. The conducted research indicates that the key factor 
of successful social innovation financing should be the extension of both financing instruments and the respective regulations. The conclusions refer primarily to the application of innovative financing instruments and the development of cross-sectoral cooperation.

Keywords: sources of financing; social innovations; financing instrument

JEL codes: D24, O25, 031

Informacje o autorze

\section{Marta Kołodziej-Hajdo}

ORCID: 0000-0002-5333-0375

Katedra Ekonomii, Finansów i Zarządzania Środowiskiem

Wydział Zarządzania

AGH Akademia Górniczo-Hutnicza w Krakowie

ul. Gramatyka 10, 30-067 Kraków

e-mail:mkolodz1@zarz.agh.edu.pl

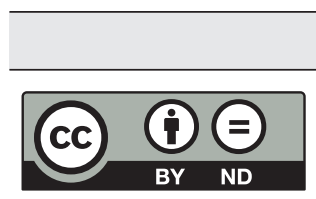

Prawa autorskie i licencja / Copyright and License

Publikacja na licencji Creative Commons Uznanie autorstwa Użycie niekomercyjne - Bez utworów zależnych 4.0 Międzynarodowe (CC BY-ND 4.0) http://creativecommons.org/licenses/by-nc-nd/4.0/deed/pl

This work is published under the terms of the Creative Commons

Attribution - NoDerivetives International (CC BY-ND 4.0) License http://creativecommons.org/licenses/by-nc-nd/4.0

Wydane przez Uniwersytet Ekonomiczny w Krakowie. Małopolska Szkoła Administracji Publicznej

Published by Cracow University of Economics - Krakow, Poland. Małopolska School of Public Administration of the Cracow University of Economics 